\title{
OBRAS EN LA COLEGIATA DE OLIVARES EN LA ÉPOCA DEL CONDE-DUQUE: LA SILLERÍA CORAL DE BERNARDO CABRERA ${ }^{1}$
}

\author{
POR ANA GOY DIZ
}

\begin{abstract}
Se analizan en este trabajo el coro y otras obras hechas por Bernardo de Cabrera en la colegiata de Olivares (Sevilla). Se estudian en profundidad tanto los elementos estructurales como los decorativos del coro, así como su influencia en obras posteriores. De la misma manera se dan interesantes noticias sobre la vida y obra del autor
\end{abstract}

The Choir and others works made by Bernardo de Cabrera in Church of Olivares (Seville), are analyzed in this paper. The architectural and decorative elements of the choir and its influence in posterior works, and so news of the life and work of the author are deal in profundity.

Muchas de nuestras iglesias encierran en sus muros episodios de un pasado glorioso a la sombra de personalidades señeras que, con sus donaciones y fundaciones, fueron los promotores de su surgimiento, mantenimiento y enriquecimiento.

Es nuestra intención analizar en este trabajo uno de tantos ejemplos: el de la colegiata de Olivares, concretamente la contratación y la elaboración de su sillería coral, una obra que durante décadas estuvo condenada al olvido, y que a raíz de su restauración, parece hacer recuperado parte de su papel.

Según se recoge en el Inventario artístico de Sevilla y su provincia ${ }^{2}$, en la parroquia de Nuestra Señora de las Nieves de Olivares se conserva una vieja sillería coral realizada hace más de tres siglos por el entallador gallego Bernardo Cabrera. Efectivamente esta obra, restaurada hace ahora quince años, fue tallada en Santiago

1. Quiero agradecer a D. Alfredo Morales Alvarez el que me hubiera facilitado las fotografías que aparecen en este trabajo.

2. MORALES,A., OLIVER,A. PLEGUEZUELO,A., SANZ, M.J., SERRERA,J.M., VALDIVIESO, E.: Inventario artístico de Sevilla y su provincia. T. I. Madrid. Ministerio de Cultura. 1982. p. 680. 
de Compostela en 1636 y trasladada en barco hasta Sevilla para ser colocada en el coro de la iglesia. El responsable de todo el proyecto fue don Francisco de la Calle, un cardenal, granadino de nacimiento y compostelano de adopción, que fue abad de la Colegiata de Olivares en los últimos años de su vida.

\section{EL CONDE DUQUE Y LA FUNDACION DE LA COLEGIATA DE LAS NIEVES}

La muerte de don Felipe III en abril de 1621 facilitó la ascensión a la cumbre de la política española del conde-duque de Olivares ${ }^{3}$ como ministro de Felipe IV. Este personaje, controvertido y ambicioso, rector de los designios de España durante más de dos décadas, fue el tercer hijo de don Enrique de Guzmán y de doña María de Pimentel y Fonseca, II Condes de Olivares, que nació en Roma en 1585, cuando su padre era Embajador de la Corte española en Italia. Desde los primeros años, su educación se orientó hacia la carrera eclesiástica y los estudios de teología, en la Universidad de Salamanca, pero la muerte prematura del primogénito, don Pedro y más tarde de don Jerónimo le obligaron a pedir la dispensa papal al convertirse en heredero del título y de la fortuna de los Condes.

En 1607, el Conde-duque fue nombrado, como sucesor de su padre, Alcaide de los Reales Alcázares y Atarazanas de Sevilla y se estableció en la ciudad, en un momento en que la situación económica de sus habitantes empezaba a debilitarse y comenzaban a percibirse los signos de la crisis económica. En su paso por el Alcazar, don Gaspar intentó continuar con las obras emprendidas años antes por su padre, y acometió la modernización de parte de las estancias reales con vistas a la visita del futuro Felipe IV ${ }^{4}$.

Pero las aspiraciones de don Gaspar no estaban en Sevilla sino en la Corte, hasta allí se trasladó para contraer matrimonio con doña Inés de Zúñiga y Velasco, sobrina de don Baltasar de Zúñiga, consejero de S.M. Este ambicioso enlace permitió entrar al Conde Duque en el entorno más próximo a la Corona, ocupando el cargo de Gentilhombre de la casa del Principe hasta la muerte de Felipe III, momento en el que, aprovechando la debilidad del nuevo rey, se convirtió en rector de la política española hasta 1643.

El Conde duque tenía el solar familiar en la villa sevillana de Olivares, en donde se encontraba el palacio levantado por su abuelo don Pedro. Esta residencia fue ampliada y enriquecida en tiempos de don Enrique de Guzmán gracias al gran número de obras de arte que trajo de Italia. Don Gaspar continuó mejorando y modernizando el palacio hasta convertirlo en una rica residencia, y a ella se retiró

3. MARAÑÓN, G.: El Conde-Duque de Olivares. La pasión de mandar. Espasa/Calpe.S.A. 1936. BROWN, J.A.: Un palacio para el Rey. El Buen Retiro y la Corte de Felipe IV. Madrid, 1981.

4. MARIN FIDALGO, A.: Vermondo Resta. n. 48. Arte Hispalense. Sevilla. Excma. Diputación provincial de Sevilla. Pp. 116-122. Sobre el viaje de Felipe IV a Andalucía vid. MERCADO EGEA, J.: Felipe IV en las Andalucías. Jaén 1980. 
en repetidas ocasiones para curarse de las profundas depresiones nerviosas que le aquejaban $^{5}$. En 1623, durante uno de estos retiros, fundó en la villa una Colegiata dedicada a Santa María de las Nieves.

En ese momento el Conde duque se encontraba en el momento álgido de su carrera política porque no había iniciado la fase bélica, y disfrutaba del respaldo del pueblo ${ }^{6}$. Durante estos años, que Marañón define como la "etapa entusiasta" de Olivares, decidió construir un mausoleo en el que reunir los restos de sus familiares. Surgió así la idea de erigir una iglesia-panteón con cripta para depositar las cenizas de los Guzmán. El diseño de la obra fue confiado a Vermondo Resta, el arquitecto milanés ligado a los Condes de Olivares desde sus primeros años en la península y que a partir de 1603 dirigió la fábrica de los Reales Alcázares.

La iglesia actual presenta una planta compleja debido a las reformas que ha sufrido (fig. 1). A Vermondo Resta podemos atribuirle las trazas iniciales de la construcción: una iglesia con cripta ${ }^{7}$, de planta basilical con tres naves separadas por columnas pareadas sobre las que se apean arcos de medio punto siguiendo, como señaló Marín Fidalgo ${ }^{8}$, la fórmula empleada en el Apeadero del Alcázar, y que Juan de Oviedo vuelve a utilizar en la iglesia del Convento de San Benito de Sevilla.

La muerte de Resta en 1625 produjo en la obra un cierto retraso que, se agudizó debido al progresivo alejamiento del Conde-duque de Sevilla. El ritmo de la construcción fue lento durante los primeros años de la década de los treinta, pero la llegada en 1636 de don Francisco de la Calle supuso un cambio en la marcha de las obras; este granadino, afincado en Galicia, aceptó el compromiso que le ofreció el Conde duque y se trasladó a Sevilla como Capellán Mayor de los Reales Alcázares y Abad de Olivares. Coincidiendo con su nombramiento se iniciaron, en 1637, las labores para la construcción de la capilla mayor de la iglesia y durante su abaciado se trabajó en la cabecera, se cerraron las bóvedas, se contrató la sillería del coro y un banco de retablo. La desaparición en $1645^{9}$ del Conde-duque no supuso el abandono del proyecto, que fue continuado hasta su conclusión en 1680 sin excesivos problemas. En 1666 se trajeron las columnas de mármol del Convento de los Remedios de Sevilla ${ }^{10}$ y se completaron las naves, manteniendo la idea inicial de Vermondo Resta.

5. MARAÑON, G.: Op. cit. p. 70 y ss.

6. Ibidem, $\mathrm{p} 47$.

7. En la cripta se depositaron los cuerpos de don Pedro de Guzmán y doña Francisca de Rivera, I Condes de Olivares, de don Enrique de Guzmán y doña María de Pimentel y Fonseca, padres del Conde Duque, y los hermanos de éste don Pedro Martín y don Jerónimo de Guzmán. (MARAÑON, G.: $O p$. cit. Apend. XII)

8. MARIN FIDALGO, A.: Op. cit (1988) p. 162

9. La partida de defunción del Conde duque fue recogida por don Gregorio Marañón en la biografía que dedica a este personaje. (MARAÑóN, G.: Op. cit. p. 419.)

10. Es entonces maestro de obras de la familia Olivares Sebastián de la Ruesta. (AA.VV: Inventario artístico de Sevilla y su provincia. Tomo I. Madrid. 1982. p. 581.) 


\section{EL CARDENAL DON FRANCISCO DE LA CALLE}

En 1633 don Francisco de la Calle, cardenal de la Santa Iglesia de Santiago, capellán de honor de Felipe IV, y entonces canónigo fabriquero de la catedral Compostelana, fue designado para ocupar el puesto de capellán mayor de los Reales Alcazares de Sevilla y abad de la Colegiata de Olivares (Sevilla). Su ilustrísima era un hombre de cuidada formación, gran experiencia y recio espíritu, que desde principios del siglo XVII había vivido en Santiago, donde ocupaba un puesto como profesor de la Universidad. Su traslado a Sevilla parece estar motivado por la difícil situación por la que atraviesa la iglesia de Olivares.

La familia de la Calle, a la que pertenecía don Francisco, era oriunda de Granada y entre sus miembros descubrimos a caballeros, regidores e inquisidores que, tuvieron un papel destacado en la ciudad, durante el reinado de Felipe IV. El cardenal era hermano de don Alonso, don Juan ${ }^{11}$ y don Pedro de la Calle Almansa ${ }^{12}$, y tío de el regidor don José ${ }^{13}$, el inquisidor don Gabriel y de don Juan de la Calle ${ }^{14}$, abogado del Santo Oficio.

Los estudios y las obligaciones religiosas de don Francisco le exigieron abandonar Granada a finales del siglo XVI, pero este hecho no supuso un distanciamiento de su familia, a la que el cardenal se mantuvo unido durante toda su vida. En su casa

11. Don Juan de la Calle fue el hermano menor de don Francisco y se crió en su casa. Era natural de Ozón y en 1622 recibió la mitad de los bienes en plata que su hermano poseía, gracias a una donación que el cardenal don Francisco furmó el 10 de septembre en Santiago. (Archivo de la Catedral de Santiago. Protocolos Notariales. Pedro Díaz de Valdivieso. n. 692-C. f. 91 r.)

12. Don Pedro de la Calle y Almansa, veinticuatro del Ayuntamiento, fue uno de los benefactores del convento franciscano de Santa Isabel la Real, una fundación real, en la que este personaje dispuso su capilla funeraria en el lateral izquierdo del templo, frente a la puerta. Todavía hoy se conserva el retablo original, que a juicio de Gómez Moreno Calera es una obra "de especial énfasis en lo monumental con un amplio encasamiento flanqueado por dobles medias columnas toscanas rematadas por frontón partido". Según Jorquera el cuadro de El Calvario que preside la capilla fue una pintura realizada por el propio Pedro de la Calle "que fue gran artífice conocido en su tiempo". (Vid. GALLEGO Y BURIN, A.: Granada. Guía artística e Histórica de la ciudad. Granada. Comares. 1993. p. 384; GÓMEZ MORENO CALERA: La arquitectura religiosa granandina en la crisis del Renacimiento (1560/1650).Monográfica de Arte y Arqueología. Granada 1989. pp. 25, 116, 228)

13. Don José de la Calle y Heredia, hijo de don Pedro, ocupó el puesto que su padre había desempeñado en el Ayuntamiento de Granada hasta 1638, y fue Procurador de la ciudad en las Cortes de 1658 en Madrid, participó en la guerra contra Francia, como Capitán "de Caballos Corazas" del ejército catalán y fue herido y apresado en la batalla. El rey Felipe IV reconoció su incondicional fidelidad y entrega y lo premió por ello. En 1661, a la vuelta de las contiendas, decidió fundar en Granada el Hospital de Tiñosos de Nuestra Señora del Pilar, en un antiguo palacio árabe del primer tercio del siglo XV que su padre don Pedro había comprado en 1630 a la Duquesa del Infantado. Actualmente el edificio, ampliado en 1939 por el Ayuntamiento está dedicado a Orfanato, pero conserva la inscripción fundacional en el zaguán de la puerta.

14. Don Juan de la Calle era, a finales de la década de los años veinte, abogado del tribunal del Santo Oficio de la Inquisción de Valladolid y alcalde de la Hermandad de Estado de los Caballeros de la ciudad. En 1629 tomó como esposa a doña Francisca Sánchez del Campo, hija de don Luis Sánchez García, secretario del rey Felipe IV. (A.C.S. Protocolos notariales. Pedro Díaz de Valdivieso. n. 693-C. f. 146 r.) 
crecieron don Juan y don Gabriel de la Calle a los que educó en Santiago ${ }^{15}$ "con todo el amor y bien" y a los que dejó gran parte de sus propiedades.

Con el nombramiento de don Francisco, como capellán mayor de los Alcázares de Sevilla, volvió a Andalucía en los últimos años de su vida y afrontó quizá el gran proyecto de toda su carrera; la construcción de la iglesia colegial de Olivares.

\section{El paso de Francisco de la Calle por el Cabildo de Santiago}

Como tantos segundones de las familias nobles, a don Francisco de la Calle se le impuso la carrera eclesiástica, y siguiendo los consejos de su pariente don Alonso de la Calle ${ }^{16}$, ingresó en la Universidad de Alcalá de Henares para estudiar Teología, llegando a obtener el título de doctor en Summas.

Durante esta etapa entró a las órdenes de don Maximiliano de Austria ${ }^{17}$ como familiar. Es posible que acompañando a su protector se traslade a Cádiz en 1596 y a Segovia en 1602. En 1603 don Maximiliano fue elegido por Felipe III nuevo arzobispo de Santiago, y a finales del verano de ese mismo año hizo su entrada en la ciudad, acompañado de toda su corte ${ }^{18}$. Entre 1603 y 1604, don Francisco llegó a Compostela, siguiendo una vez más los pasos de su buen amigo. En noviembre de 1607 ya era canónigo y mayordomo particular del arzobispo ${ }^{19}$ y se ocupaba de la administración de la residencia del prelado. Pronto su situación económica mejoró al asignársele las rentas de algunas tenencias del Cabildo y desempeñar cargos en la Mesa capitular ${ }^{20}$. En distintas ocasiones actuó como representante del Arzobispo,

15. A. C. S. Protocolos notariales. Pedro Díaz de Valdivieso. $n^{\circ}$ 692-C. f. 91

16. Don Alonso de la Calle fue mayordomo de don Maximiliano de Austria durante la etapa que éste pasó estudiando en la Universidad de Alcalá de Henares y en 1582 tomó posesión de la silla abacial de Alcalá la Real (Jaén), en nombre de su señor. (HOYO, J. de: Memorias del arzobispado de Santiago. Santiago. 1612. p. 34)

17. Don Maximiliano de Austria era hijo natural del archiduque don Leopoldo, nieto del emperador Maximiliano II de Alemania, y primo del rey Felipe II. En un principio su vida fue encauzada hacia la carrera militar, pero las dotes de mando y las aptitudes que demostraba el joven, hicieron sentir recelo al propio rey, que decidió orientar a su primo hacia la carrera eclesiástica. Sobre esta interesante figura nos remitimos a los trabajos de HOYO, J. de: Memorias del Arzobispado de Santiago. Santiago. 1612. LOPEZ FERREIRO, A.: Historia de la S.I.A.M. de Santiago. Santiago. 1907. T. IX. pp. 7-41., JUAN LOVERA, C.: "Presencia de Jaén y Alcalá la Real en Santiago de Galicia". Jaén. 24, febrero de 1979.; "Don Maximiliano de Austria, giennense, abad de Alcalá la Real, arzobispo de Santiago, y Don Juan de Austria, el vencedor de Lepanto". Jaén. 24 de Septiembre de 1978. "El Abad don Maximiliano de Austria (1555-1614). Fuente del Rey. n. 58. Priego de Córdoba, 1988.

18. GOY DIZ, A.: "La entrada triunfal del arzobispo don Maximiliano de Austria en Santiago de Compostela". Revista a la Patrona de Alcalá la Real (Jaén) Agosto 1994. Pp. 76-79.

19. Carta de pago de Don Antonio de Ozores, mayordomo del Hospital Real, al canónigo de la Calle, mayordomo del Arzobispo Maximiliano de Austria. (A.C.S. Prot. n. 643. f. 162).

20. En 1615 es nombrado administrador de la Capilla del Rey de Francia. (A.C.S Actas Capitulares 1615-1621. f. 46. Cabildo celebrado el 21 de Septiembre de 1615) 
y concretamente en 1608 fue nombrado administrador de los bienes y juros del canónigo Juan Abraldez ${ }^{21}$, durante el tiempo que don Maximiliano estaba en la Corte ${ }^{22}$.

Sus intervenciones en el Cabildo son entonces prudentes y esporádicas, porque mientras otros familiares del arzobispo, como Jerónimo del Hoyo o Carrillo Aldrete, centraron su trabajo en el marco de la Mesa Capitular, el canónigo de la Calle se mantuvo al márgen y repartió su tiempo entre la organización del Palacio Arzobispal y la docencia universitaria ${ }^{23}$. Esta situación varió a partir del fallecimiento de don Maximiliano, el 1 de julio de 1614. En su testamento, el arzobispo dispuso la designación de sus testamentarios (los canónigos Carrillo de Aldrete, Hoyo, PadillaMedina ${ }^{24}$ y de la Calle ${ }^{25}$ ) como cardenales de la Santa Iglesia de Santiago, y don Francisco, como albacea, quedó vinculado a la ciudad de Santiago hasta el momento en que se cumplieron todas las mandas testamentarias del difunto.

La desaparición de don Maxiliano, liberó al canónigo de gran parte de sus obligaciones, que pudo centrarse en su labor pedagógica y en sus compromisos capitulares ${ }^{26}$. A partir de entonces, las intervenciones en las sesiones del Cabildo fueron cada vez más frecuentes y su posición en el seno de la Mesa Capitular se fortaleció; prueba de ello es que en 1621 fue nombrado Diputado en el LVII Sínodo Compostelano ${ }^{27}$.

La muerte de don Juan Beltrán de Guevara, un año más tarde, abrió un período de inestabilidad en la sede compostelana, al sucederse en apenas siete años tres arzobispos. Esta situación permitió el reforzamiento de algunos miembros del Cabildo, entre ellos el cardenal de la Calle que, disfrutó de una posición privilegiada para poder actuar libremente. Este período de cierta inestabilidad favoreció los enfrentamiento entre los capitulares, que luchaban violentamente por la defensa sus propios intereses.

En 1626, Francisco de la Calle ocupó el cargo de canónigo fabriquero de la Catedral, y en ese momento se desencadenó una de las polémicas habituales. Cuatro años antes, en 1622, había fallecido el arzobispo don Juan Beltrán de Guevara, y sus testamentarios habían decidido depositar los restos de su benefactor en un

21. A.C.S. Prot. n. 686-D. f. 32.

22. LOPEZ FEREIRO, A.: Op. cit. T. IX. pp. 20-23.

23. En las actas del Claustro de la Universidad celebrado el 16 de Marzo de 1612, se recoge la noticia de la limosna de 50 ducados que el canónigo Francisco de la Calle ofreció a la fábrica para la reparación de las infraestructuras de los colegios. (Archivo Histórico Universitario de Santiago. Universidad. Libros de Claustros. 1609-1614. f. 287 v.)

24. Don Jerónimo Padilla y Medina fue el representante del arzobispo en la toma de posesión de la sede gaditana el 6 de marzo de 1597. (Vid. HOYO, J. de: Op. cit. p. 34)

25. HOYO, J. de: Op. cit. p. 36.

26. En 1618, don Francisco de la Calle y el licenciado Hermosilla, como representantes del Cabildo compostelano, contrataron a una compañía de comediantes dirigidos por Pedro de Callenueva para que amenizaran las fiestas del Corpus en la ciudad. (A.C.S. Protocolos Notariales. Pedro Díaz del Valdivieso. n. 691-C. f. 46)

- 27. En el Sínodo fueron designados, junto a Francisco de la Calle, los licenciados Sanz del Castillo, y los doctores Méndez de Andrade y Cangas. (LOPEZ FERREIRO, A.: Op. cit. pp. 53) 
sepulcro en el segundo tramo de la girola de la catedral, entre las capillas de San Fructuoso y San Andrés ${ }^{28}$.

El proyecto fue confiado a Francisco González Araujo, el Mozo, por entonces maestro de obras de la catedral. Éste diseñó un sepulcro en piedra, adosado a la pared, con la figura del difunto orante, cobijada por un enmarque arquitectónico. La obra debió de agradar a los testamentarios, el Obispo de Buxía y el licenciado Juan Bautista de Herrera, pero molestó profundamente a los familiares del arzobispo Sanclemente y de don Maximiliano de Austria, grandes benefactores de la diócesis y, sin embargo, relegados a la frialdad de una simple lápida en el suelo del crucero. Las vehementes protestas de los canónigos, encabezados por don Francisco de la Calle, obligaron a abandonar el proyecto inicial y a nombrar a una comisión presidida por el fabriquero, por el doctor Villafañe y por el licenciado Suárez de Figueroa con el objeto de buscar una salida a la cuestión. En la exposición de su postura ante el dean, don Francisco de la Calle fue rotundo al afirmar que: "gracia como esta de enterrarse frente al sepulcro del glorioso apostol a nadie se habia hecho, ni aun a las personas reales" ${ }^{29}$, por eso recomienda al arzobispo que, si permite realizar el sepulcro, "mire mucho el modo y las circunstancias de su obra y fabrica y que no se exceda a la veneracion y respecto que se deve a la presencia del sepulcro del glorioso apostol..." 30.

Aprovechando las posibilidades que el cargo de fabriquero le brindaba, don Francisco de la Calle hizo su propia propuesta para la tumba del arzobispo, y presentó las trazas junto a las de Francisco González Araujo, el Mozo, y Bartolomé Fernández Lechuga, maestro de San Martín. La comisión eligió el diseño firmado por este último, por ser la solución menos comprometida ${ }^{31}$.

A partir de esta intervención, el canónigo de la Calle aparece continuamente en la documentación. El prestigio y la confianza, ganados ante sus más directos adversarios, lo convirtieron en uno de los personajes destacados del Cabildo, por eso en 1626 fue elegido, junto a don Julián de Cangas, para desempeñar el puesto de vicario capitular, a la muerte del arzobispo don Agustín Antolínez ${ }^{32}$. En 1629 renunció al cargo de fabriquero ${ }^{33}$, que volvió a desempeñar en $1632^{34}$.

Durante estos años, la Fábrica de la Catedral atravesó por momentos de grave penuria económica que obligaron a los capitulares a dedicar un porcentaje de los ingresos dispuestos inicialmente para las obras, a cubrir las necesidades de los indegentes de la ciudad. Así en abril de 1632, don Francisco de la Calle hizo entrega,

28. Con esta decisión se rompía la costumbre de los últimos arzobispos de enterrarse en el suelo de la catedral, en el espacio que se encontraba entre el altar y el coro. Vid. GOY DIZ, A.: La arquitectura en Galicia en el paso del Renacimiento al Barroco (1600-1650): Santiago y su área de influencia. Santiago. Xunta de Galicia. 1995 (en prensa).

29. A.C.S. Actas capitulares. 1625-1626. cit. LOPEZ FERREIRO, A.: Op. cit. T. IX. pp. 61.

30. Ibidem.

31. BONET CORREA, A.: La arquitectura en Galicia en el siglo XVII. Madrid. 1989. p. 158.; GOY DIZ, A.: Op. cit. pp. 1219-1236; pp. 1460-1465.

32. LÓPEZ FERREIRO, A.: Op. cit. T. IX. p. 72.

33. A.C.S. Actas capitulares. 1627-1621. Libro XXVI. f. 63 v.

34. A.C.S. Actas capitulares. 1631-1635. Libro. XXVI. f. 55. 
al canónigo León y Jacinto Martínez, de 800 ducados extraídos del Arca del Apóstol, con el fin de que los repartiera equitativamente ${ }^{35}$ entre la población.

\section{La marcha del cardenal de la Calle a Sevilla}

A finales de 1632 se conoció en Compostela la noticia de que don Francisco había sido nombrado abad de la Colegiata de Olivares, y que debía de trasladarse a Sevilla. Inmediatamente su sobrino don Gabriel de la Calle se hizo cargo de todas las propiedades, prebendas ${ }^{36}$ y tenencias de su tío ${ }^{37}$, y supervisó algunas cuestiones relacionadas con el testamento de don Maximiliano que estaban todavía sin solventar ${ }^{38}$. En un intento por mantenerse en Santiago, don Francisco reclamó su cátedra de Teología en la Universidad, pero de nada sirvió, y en el otoño de 1633, abandonó definitivamente Compostela.

La vacante que dejó en el Cabildo y en el Colegio de Santiago Alfeo fue ocupada inmediatamente por su sobrino, don Gabriel de la Calle y Heredia. Éste fue nombrado cardenal de la iglesia de Santiago ${ }^{39}$ en 1634 , en mayo de 1635, administrador de las rentas de Granada ${ }^{40}$, en 1637 rector del Colegio de Santiago Alfeo ${ }^{41}$, en 1645 Inquisidor Apostólico del Reino de Galicia ${ }^{42}$, y en 1647 Inquisidor electo del Reino de Aragón ${ }^{43}$.

Desde 1635 hasta 1636, don Gabriel de la Calle realizó numerosos viajes a Granada como prebendado del Cabildo y aprovechó estas visitas para entrevistarse con su tío y el arzobispo don Martín Carrillo de Aldrete.

Quizá, en uno de estos encuentros, tío y sobrino, conscientes de la necesidad que el templo de Olivares tenía de una sillería coral ${ }^{44}$, decidieron financiar su construcción, y don Gabriel se convirtió en el verdadero artífice del contrato de la obra.

35. A.C.S. Actas capitulares. 1631-1635. Libro. XXVII. f. 79 v.

36. A.C.S. Actas Capitulares 1631-1635. Libro XXVII. f. 195 r.

37. A.C.S. Actas Capitulares. 1631-1635. Libro. XXVII. f. 119.

38. A.C.S. Actas Capitulares. 1631-1635. Libro. XXVII. f. 151 v.

39. A.C.S. Actas Capitulares. 1631-1635. Libro. XXVII. f. 270.

40. Las rentas que percibía el Arzobispado provenían de tres regiones: Galicia, Castilla y Granada. En esta última ciudad tanto la mesa arzobispal como capitular contaban con un prebendado que recogía las rentas de los Votos del Arzobispado de Toledo de la margen derecha del Tajo, del arzobispado de Sevilla, de Córdoba, de Jaén, de Badajoz, de Cuenca y de Cartajena. (HOYO, J. de: Op. cit. p. 37)

41. A.C.S. Actas Capitulares. 1637-1647. f. 37 v.

42. A.C.S. Bartolomé Rodríguez Otero. Protocolo n. 645-G. f. 476.

43. A.C.S. Domingo de Leirado. Protocolo n. 648-A. f. 163 r.

44. La Colegial de Olivares contaba, a finales del siglo XVI, con dos importantes fuentes de ingresos: las partidas anuales asignadas por los Condes de Olivares y los diezmos correspondientes a las villas de Albaida, Heliche, Sanlúcar la Mayor, Castilleja de Guzmán y parte de Castilleja de la Cuesta. A principios del siglo XVII estos ingresos fallan. El Conde don Enrique de Guzmán invierte la casi totalidad de las rentas asignadas a Olivares en la fundación del Monte Fideicomiso. El Conde-duque don Gaspar de Guzmán respaldó esta iniciativa, sin que nadie se atreviera a cuestionar la medida adoptada. Por lo que se refiere a los diezmos, Olivares entró en litigio con el Arzobispado de Sevilla que se negó a reconocer la jurisdicción de la colegial sobre las villas antes citadas y por lo tanto la posibilidad de percibir ingresos. El enfrentamiento entre Olivares y Sevilla se prolongó hasta los años centrales del siglo $\mathrm{XVII}$, teniendo que renunciar el abad a parte de los territorios que le correspondían. 


\section{EL ENTALLADOR BERNARDO CABRERA}

Bernardo Cabrera fue el entallador que recibió la confianza del abad de Olivares y realizó la sillería coral de la colegiata, en 1636. Los datos que contamos de su vida y de su obra indican que fue un hombre que trabajó en Galicia durante gran parte de la primera mitad del XVII y que fue considerado por sus contemporáneos como una de las figuras más interesantes en el mundo de la retablística. Las últimas investigaciones han descubierto datos importantes sobre su formación, situación social y familiar, estilo y obras, por lo que resulta necesario una revalorización de esta figura, hasta ahora simplemente conocida por ser el introductor de las columnas salomónicas en España ${ }^{45}$.

Los orígenes artísticos de este maestro, están según las investigaciones del profesor García Iglesias ${ }^{46}$, en Orense, en el monasterio de Oseira donde trabajó, formando parte de los últimos talleres manieristas. En 1625, el artista está en Santiago para participar en el concurso convocado por la Mesa Capitular con el objeto de elegir las trazas para el retablo de la Capilla de las Reliquias ${ }^{47}$ de la Catedral. Al concurso se presentaron también Francisco de Moure y Francisco Dantas Franco, pero fue el joven Cabrera el que con sus dos diseños ganó la confianza de los capitulares. Era por entonces "fabriquero y obrero mayor de la Fábrica

45. PEREZ COSTANTI, P. Diccionario de artistas gallegos que florecieron durante los siglos XVI y XVII. Santiago 1933. Pp. 73-76.; OTERO TUÑEZ, R.: "Las primeras columnas salomónicasde España". Boletín Universidad Compostelana. 63. (1955). Pp. 335 y ss. BONET CORREA, A.: La arquitectura en Galicia durante el siglo XVII. Madrid. 1966. Pp.260-267. LIMIA GARDON, F.J.:"Varia artística de la provincia de Orense en el siglo XVII". Boletín Auriense, X. (1980). Pp. 227.244. HERVELLA VAZQUEZ, J.: La escultura en el deambulatorio de la Catedral de Orense. Teis de licenciatura inédita. 1985; LIMIA GARDON, F.J.: La Epoca Moderna en el Monasterio cisterciense de Oseira. Cincuenta años de restauraciones. León 1988.; HERVELLA VÁZQUEZ, J.: "En el camino a Damasco: La coversión de San Pablo, tema escultórico de la Capilla de Armada en la Catedral de Orense". Actas VI Congreso de C.E.H.A. "Los Caminos y el arte". Santiago. 1989. III. Pp. 119-127.; FERNANDEZ GASALLA, L: "La autoría del retablo de Montederramo: Bernardo Cabrera y su hijo Juan de Cabrera, retablistas del escultor Mateo de Prado". Brigatium, VI (1989-1990). p. 175 y ss.; HERVELLA VÁZQUEZ, J.: "La capilla de la Asunción o de Argiz en la catedral de Ourense. La ascendencia orensana del primer marqués de San Saturnino". Porta da Aira. III. (1990); GARCIA IGLESIAS, J.M.: A Catedral de Santiago o o Barroco. Santiago. 1990; FERNANDEZ GASALLA, L.: Aportación documental sobre a actividade artistica compostelana entre 1649 y 1686 . Tésis de licenciatura inédita. Santiago. 1991.; GARCIA IGLESIAS, J.M.: "Bernardo Cabrera, arquitecto-entallador del Barroco Gallego". Estudios sobre Historia del Arte ofrecidos al Profesor Dr. Don Ramón Otero Túñez en su 65 cumpleaños. Madrid. 1993. Pp. 201-213.

46. GARCIA IGLESIAS, J.M.: "Bernardo Cabrera... p. 201. Vid. nota 1. (LIMIA GARDON, F.J.: La Epoca Moderna en el Monasterio cisterciense de Oseira. Cincuenta años de restauraciones. León 1988. p. 78)

47. La capilla de las Reliquias o de los Reyes es una de las dependencias anejas al claustro de la Catedral, que se encuentra situada entre éste y la nave lateral de la Epístola. Durante años sirvió como Sala Capitular, pero a comienzos de la centuria, al construir un nuevo salón de reuniones en la galería occidental del claustro, se acondicionó como capilla relicario. El proyecto se inició en 1617 con la construcción de una serie de enmarques arquitectónicos sobre las Tumbas Reales. Vid. GOY DIZ, A.: La arquitectura en Galicia ... Santiago. Xunta de Galicia. 1995. (en prensa) Pp. 1225 y ss. 
y Obra de la Santa Yglesia de Señor Santiago" ${ }^{48}$ el cardenal don Francisco de la Calle. Esta es la primera vez que ambos personajes coincidieron.

La envergadura y relevancia del retablo de las Reliquias animaron al Cabildo a habilitar, en las dependencias próximas al claustro, unos amplios talleres en donde Cabrera y el viejo escultor Gregorio Español ${ }^{49}$ pudieron tallar las piezas.

El proyecto de las Reliquias brindó al entallador la oportunidad de trabajar con Gregorio Español, uno de los escultores mejor considerados de la época por su intervención, junto a Juan Davila, en el magnífico coro de la catedral de Santiago ${ }^{50}$. En colaboración, Cabrera y Español, contrataron el retablo de la capilla de Jerónimo de Sarabia, en el convento de San Francisco de Vigo (Pontevedra) ${ }^{51}$ y el de la capilla de doña Mencía de Andrade en el deambulatorio de la catedral de Santiago ${ }^{52}$.

La muerte de Gregorio Español supuso un cambio importante en la carrera de Bernardo Carbrera, que tuvo que buscar a un nuevo escultor para que colaborara con su taller. Mientras se concluyó el retablo de las Reliquias, Cabrera trabajó en otros proyectos fuera de la catedral. En 1631 contrató en solitario el retablo mayor del monasterio de San Juan de Poio (Pontevedra) ${ }^{53}$, trabajó en la capilla mayor de la ermita de Nuestra Señora de la Cerca de Santiago ${ }^{54}$, y en el retablo de la capilla de San Damián en San Juan de Abruciños (Ourense) ${ }^{55}$ que financió don Pedro Fernández de Boan. En los primeros días de 1635 el fabriquero, don Juan de Astorga y del Castillo, le confió los canceles para las puertas de la Quintana y Platerías de la catedral ${ }^{56}$.

En este momento Bernardo Cabrera tenía un importante taller, gozaba de fama en la región y disfrutaba de una buena posición económica. Fue entonces cuando Francisco de la Calle le contrató la realización de una sillería coral y un retablo para la colegiata de Olivares (Sevilla) ${ }^{57}$.

48. Contrato de las figuras de la capilla de los Reyes en la Catedral de Santiago. (A.C.S. Colección de documentos sueltos. $\mathrm{n}$. 409. duplic.)

49. Sobre Gregorio Español vid. VILA JATO, M.D. La escultura manierista en Galicia. Colección Arte Galega Sánchez Cantón. Santiago de Compostela. 1983. Pp. 108-110-

50. En relación al coro vid. ROSENDE VALDES, A.A.: "El antiguo coro de la catedral de Santiago". Compostellanum. 1978.

51. A.C.S. Colección de Documentos Sueltos. VI. Doc. 445. Cit. PEREZ COSTANTI, P. : Diccionario de artistas... p. 75.

52. A.C.S. Colección de Documentos Sueltos. VI. Doc. 441. Sobre la capilla de Doña-Mencía de Andrade Vid. GOY DIZ, A.: "La capilla de Doña Mencía de Andrade en la catedral de Santiago". Compostellanum. XXXVII. (1992). Pp. 609-625.

53. A.H.U.S. Protocolos notariales. Pedro das Seixas. Prot. n. 859. f. 883 r.

54. PEREZ COSTANTI, P.: Dicconario de artistas.... p. 75.

55. Sobre la fundación de esta capilla Vid. GONZALEZ GARCIA, M.A.: "La capilla de los Boán en Abruciños". Boletín Auriense. II. (1972). Pp. 7-74.

56. A.H.U.S. Protocolos notariales. Pedro de Valdivieso. Prot. n. 1758. f. 96 r.

57. A.H.U.S. Protocolos Notariales. Pedro de Valdivieso. Prot. n. 1761. f. 830 r. 


\section{LA SILLERIA CORAL DE LA COLEGIATA DE OLIVARES}

El hallazgo del contrato de la sillería de Olivares aporta datos muy interesantes sobre la realización de la obra que sólo en parte se conocían a través del trabajo de Gil Bermejo ${ }^{58}$. Según el documento, el ilustre don Francisco de la Calle comenzó su abaciado con el proyecto de continuar con las obras de la cabecera de la iglesia y la construcción del coro. La propuesta fue aprobada el 13 de septiembre de 1635 por el Cabildo de la Colegiata, que respaldó la idea. Ésta consistía en "la hechura y obraxe de beinte y una sillas altas y catorce sillas baxas con sus quatro escaleras que ... se an de açer para asentar en el dicho coro que nuevamente se esta fabricando en la dicha yglesia colexial... y ansi mismo una custodia y un banco de retablo que se le pide por otra memoria..." 59 .

Bernardo Cabrera estudió las condiciones e hizo las trazas de la obra que, posiblemente remitió a Olivares a principios de 1636 . El abad, una vez analizado el proyecto, corrigió el diseño recibido y redactó un nuevo pliego de condiciones que, vinieron a completar las presentadas por el entallador. En noviembre de ese mismo año, don Gabriel de la Calle recibió en Santiago las modificaciones a la propuesta de Cabrera, y firmó con éste el contrato de la obra ${ }^{60}$. Entre las novedades que don Francisco de la Calle exigió estaba "que el dicho Bernardo Cabrera a de hyr a asentar las sillas y mas obra en la dicha iglessia colexial de la dicha villa de Olibares y dexarlas de todo punto asentadas, acavadas, ajustadas y perfeçiona$d a s^{\prime \prime}{ }^{1}$, corriendo por cuenta de la colegial los gastos que se pudieran ocasionar por el viaje del maestro y de un aprendiz. Asimismo se obligó al artista a confeccionar la serie de cajas para el embalaje de las piezas que serían transportadas por mar desde el puerto gallego de Corcubión (La Coruña) a Sanlúcar de Barrameda ${ }^{62}$, de allí al Puerto de Triana, y en carretas y mulas hasta Olivares.

De todas las condiciones presentadas por el cliente, la que más preocupaba al artista era la de tener que trasladarse para asentar la obra. Bernardo Cabrera tenía, a mediados de la década de los treinta, importantes compromisos que atender, por lo que fue necesario que el cardenal, consciente del esfuerzo que suponía para el

58. En 1984, al término de la restauración del coro, se publicó un documento conservado en el Archivo Parroquial de Olivares (Sevilla) en el que se recoge la relación de gastos que supuso la construcción y el traslado de la obra desde Santiago de Compostela al puerto de Sanlúcar de Barrameda y desde allí a la colegiata. (Vid. GIL BERMEJO, J.: "Datos sobre la Colegiata de Olivares: Silleria del Coro". Archivo Hispañense. $2^{a}$ Época. LXVII. n. 205. (1984). Pp. 169-177.)

59. A.H.U.S. Protocolos notariales. Pedro de Valdivieso. Prot. n. 1761. f. 830 r.

60. "Y todo pareze en la planta del dicho coro en que se les a de añadir y pareze en la planta del dicho coro en que se les a de añadir y mudar lo que esta scrito de letra del Señor Olibares que queda con esta scritura".

61. Ibidem, f. $836 \mathrm{v}$.

62. El transporte en barco sumó 1000 reales, a los que habría que añadir los 652 reales del traslado de Santiago de Compostela a Corcubión (La Coruña), los 150 de Sanlúcar a Triana y los 154 reales por los portes de las nueve carretas que trasladaron las cajas hasta Olivares. (GIL BERMEJO, J.: Op. cit. p. 175) 
artista, incrementara las partidas referidas a la "hechura" de la obra, al viaje y al salario del maestro. Primeramente don Gabriel de la Calle compró la madera, los clavos y las visagras, y entregó dos mil reales a Cabrera para que comenzara a trabajar en el proyecto. A esta cantidad había que añadir los tres ducados y la fanega de centeno que el canónigo entregaría a la mujer del artista para el sustento de la casa, durante el tiempo que su marido estuviera de viaje y, los 540 ducados (5.940 reales) que recibiría cuando concluyese la obra.

Según la relación de gastos que se conserva en el Archivo Parroquial de Olivares ${ }^{63}$, a todo lo contratado, el abad y los prebendados de la colegial añadieron como gratificación cien ducados, que le entregaron a Cabrera poco antes de emprender éste el viaje de regreso a Santiago.

El importe total de la obra se cifró en 13.422 reales, de ellos 1.063,5 reales se invirtieron en materiales, 2.059 en gastos de transporte, 1.819 en jornales de peones, 1.424 en el pago del viaje de Bernardo Cabrera y 6.836 en concepto de hechura u "obra de manos" 64 .

\section{Características de la obra}

Como planteabamos al principio, la sillería de Olivares ha sufrido importantes alteraciones a lo largo de estos tres siglos, que han obligado incluso a trasladar el coro desde el primer tramo de la nave, a los pies de la iglesia, donde se encuentra en la actualidad (Lám. 2).

Según las condiciones establecidas en el contrato, el coro de Olivares constaba de treinta y una sillas con sus respectivos atriles y misericordias, que ocupaban la anchura total de la nave mayor $\left(8^{1 / 3}\right.$ varas de ancho) y la profundidad del tramo de los arcos torales $\left(6^{1 / 2}\right.$ varas de largo), aproximadamente $6,60 \mathrm{~m} . \times 5,25 \mathrm{~m}$. El coro alto estaba formado por siete sitiales por lado y el coro bajo por cinco, con la excepción del cierre del testero en el que únicamente fue posible disponer cuatro asientos (Lám. 3-4).

Como era habitual el acceso se realizaba a través de dos puertas: una en el lado del Evangelio, y otra en el lado de la Epístola, junto a ellas se encontraban dos de las escaleras de subida al coro alto, las otras dos se situaban en el testero "las quales se an de poner despues de la silla de junto al rincon, cada una de un lado, de manera que queden dos sillas en medio, cuyos respaldos han de subir para haçer sitial a la silla principal".

Tanto para las sillas altas como para las bajas se utilizó, según el contrato, el orden corintio con el fuste decorado con estrías helicoidades en el tercio inferior y

63. GIL BERMEJO, J.: Op. cit. p. 175.

64. En el contrato se establece que por cada silla Bernardo Cabrera cobre 3,5 ducados/silla, 13,5 ducados /escalera, 13,5 ducados/ compartimentos próximos a la silla abacial. 
verticales en los tercios superiores. En los repaldos aparecen trabajos de talla a base de formas geométricas: rombos, cuadrados, elipses y círculos en resalte que recuerdan labores de marquetería (Lám. 5).

Los tableros no presentan labor escultórica, ésta se concentra en el friso, donde aparecen una serie de motivos geométricos en los que se conjugan cartelas, bolas y óvalos. La cornisa se decora con florones, dos por sitial, separados por medio de modillones ${ }^{65}$. Coronando el conjunto se disponían cartelas y remates de pirámides y bolas, de las que no se conserva ninguna.

La silla del abad fue la pieza más cuidada de toda la obra (Lám. 6). El respaldo lo flanquean columnas de orden compuesto con el tercio inferior del fuste decorado con el escudo de armas del cardenal. En el tablero, según señalaba el contrato, Cabrera tenía que tallar un relieve del Nacimiento " conforme al dibuxo que para ello se le entregare" y sobre él colocar el escudo de armas de los patrones de la iglesia, los Condes de Olivares, que sería tallada por el escultor sevillano Gaspar Ginés ${ }^{66}$ y que desgraciadamente se ha perdido.

La recomposición de la sillería ha alterado de forma traumática la obra. Han variado el acceso al coro, que ahora se realiza a través del testero, han modificado las escaleras, han suprimido los tableros y el entablamento de las sillas bajas, y han incrementado el número de asientos laterales (de 7 a 9 en las sillas altas y de 5 a 7 en las bajas) al tiempo que han reducido los del tesetero (de 7 a 5 , y de 4 a 2 ). El resultado es caótico y el aspecto actual de la obra apenas responde al proyecto inicial.

\section{Analisis estilístico}

El estado actual de la sillería no permite un análisis estilístico, por lo que simplemente intentamos una aproximación a los motivos decorativos que aparecen en la obra y especialmente al relieve que preside el sitial del abad.

Primeramente debemos de considerar que la experiencia de Bernardo Cabrera en la realización de sillerías corales debía de ser escasa cuando fue contratado por don Francisco de Calle, por lo que se limitó a repetir fórmulas ya conocidas y consagradas en sillerías como la del monasterio de Montederramo, de su maestro Alonso Martínez, de la catedral de Santiago de Juan Davila y Gregorio Español ${ }^{67}$, o de la de Lugo de Francisco de Moure ${ }^{68}$, en cualquiera de ellas encontramos importantes analogías en cuanto a la distribución de sitiales, el tipo de enmarque arquitectónico, la organización de la cornisa o del tipo de asiento. La principal diferencia estriba en que la sillería de

65. Según Gil Bermejo los florones se deben al entallador Luis de la Aya, El Viejo, que comenzó a trabajar el 30 de agosto de 1638 en la obra. (GIL BERMEJO, J. :Op. cit. p. 170)

66. GIL BERMEJO, J.: Op. cit. p. 176.

67. VILA JATO, M. D. : La escultura manierista en Galicia. Santiago. 1985.

68. En relación con esta obra vid. VILA JATO, M. D.: Francisco de Moure. Santiago. Xunta de Galicia. 1991. Pp. 96 y ss. 
Olivares carece del programa iconográfico que enriquece los ejemplos antes citados. La única concesión en este aspecto es el relieve que decora el repaldo de la silla abacial, en el que se dispone la tabla del Nacimiento.

El relieve del Nacimiento de Cristo se concibe como una escena sencilla en su composición y organizada en dos planos: el más cercano al espectador, en el que se disponen los tres personajes, San José, la Virgen y el Niño y, un plano de fondo con un relieve muy degradado donde se articulan unas arquitecturas estilizadas. El tipo de plegado se caracteriza por un tratamiento de las telas a base de grandes pliegues de curvas amplias y superficies redondeadas que, caen rítmicamente.

Hasta ahora, en distintas publicaciones se ha relacionado esta obra con el hacer de la escuela sevillana, y concretamente se manejó el nombre de Gaspar Ginés como el posible autor del relieve. Nosotros sin embargo, en el transcurso de la investigación hemos encontrado algunos datos que nos inducen a plantear como dudosa esta atribución. En principio porque en el contrato se especifica detalladamente como Bernardo Cabrera debe de seguir con fidelidad el diseño enviado por el canónigo de la Calle. En segundo lugar porque en la relación de gastos no se hace mención alguna al pago del relieve a otro maestro, por lo que consideramos que la escena del Nacimiento probablemente es una obra del taller de Cabrera que, sigue el modelo de una estampa andaluza. La cuestión es cuáles pudieron ser las fuentes para esta imagen.

Los trabajos, antes citados, de Gil Bermejo ${ }^{69} \mathrm{y}$ Morales ${ }^{70}$ señalan la influencia en el relieve de Olivares de formas montañesinas. Por los años treinta, Martínez Montañés ${ }^{71}$ regentaba el taller de talla más importante de la ciudad de Sevilla y, su fama y su valía le habían hecho merecedor de la confianza del rey. El entallador pudo sugerir al canónigo de la Calle el diseño del respaldo, sin embargo no hemos localizado dato alguno que vincule a este maestro con la familia del Conde-duque, ni con la villa de Olivares, y aún cuando sabemos del éxito y de la popularidad de sus obras, no deja de sorprendernos el hecho de que no haya constancia de esta relación.

Existen sin embargo otros dos artistas que mantuvieron una estrecha relación con la villa y la familia del Conde-duque; uno fue el pintor Juan de Roelas y el otro, Alonso Cano.

Juan de Roelas fue, según Valdivieso ${ }^{72}$, una de las figuras más atractivas de la escuela de pintura sevillana del primer tercio del siglo XVII, aunque su personalidad ha quedado eclipsada por la de los grandes maestros locales como Zurbarán, Murillo y Valdés Leal.

Roelas fue un clérigo que compaginó durante toda su vida la labor pastoral con la pictórica. A principios del siglo XVII aparece como capellán de la iglesia de Olivares, en donde residió durante al menos diez años, hasta su marcha a Madrid. Su estancia en la Corte, junto a Carducho y Gómez de Mora, le brindó la oportunidad de trabajar

69. GIL BERMEJO, J.: Op. cit. pp. 169-177.

70. MORALES, A. el alt: $O p$. cit p. 680.

71. HERNÁNDEZ DÍEZ: Juan Martínez Montañés. Sevilla. 1949.

72. VALDIVIESO, E.: Juan de Roelas. Sevilla 1979. 
en las empresas reales más destacadas. Tras su paso por la capital, volvió a Andalucía en 1619 y murió en Olivares en 1625.

La prolongada estancia de Roelas en la villa tuvo necesariamente que dejar su huella a través de cuadros, bocetos y grabados.

El tercer maestro ligado a la familia del Conde-duque fue Alonso Cano. Desconocemos las causas por las que don Gaspar se interesó por él, Palomino señala como uno de los motivos para que el maestro saliera de Sevilla, el lance ocurrido con Valdés Leal ${ }^{73}$, pero sea como fuere, hacia 1637, don Gaspar, quizá aserorado por Diego de Velázquez, supo de la valía de este maestro y, quizá siguiendo el consejo del pintor le propuso trasladarse a Madrid. En 1638, en presencia del propio Velázquez y Juan de Pareja, Cano vende sus propiedades en Sevilla, dispuesto a marcharse a la Corte ${ }^{74}$ con el cargo de pintor y ayudante de Cámara del Conde-duque de Olivares.

De esta relación no han quedado demasiadas muestras, los primeros biógrafos de don Gaspar de Guzmán no hacen referencias a retratos del Conde y su familia, pero si recogen la noticia de la entrega de un Crucificado firmado por Alonso Cano a las dominicas de Loerches, durante su exilio.

Es posible que en 1636, cuando se contrata la sillería, Alonso Cano entregara a su protector un dibujo, de los muchos que él realizaba, para la silla abacial de la Colegiata de Olivares.

La falta de datos documentales no permite avanzar en el tema, y lo único que sabemos es que sobre un grabado o estampa, un escultor gallego hizo un relieve del Nacimiento que hoy preside toda la obra. Rastrear la posible influencia de cada uno de estos maestros es difícil, pero al menos podemos señalar como la composición del respaldo recoge el eco de algunas obras de Roelas como la Adoración de los Pastores (1619-1624) del retablo de la Merced de Sanlucar de Barrameda (Lám. 7).

En este lienzo se observa la concentración de los personajes en la parte inferior del cuadro, como ocurre en el relieve del Nacimiento de Olivares. La Virgen aparece en una actitud amorosa, cubriendo al Niño con los pañales, mientras que San José ${ }^{75}$ contempla la escena, en actitud orante, desempeñando un papel similar al de María ${ }^{76}$. Desde el punto de vista iconográfico, el pasaje ha ganado en relevancia, y el pesebre ha dejado de ser el lugar oscuro y olvidado, para convertirse en el escenario en el que el Hijo de Dios viene al mundo en presencia de la Divinidad, de ahí que, en la parte

73. PALOMINO: Vidas. Madrid. Alianza/Forma. 1986. p. 249

74. WETHEY, H.E.: Alonso Cano. Pintor, escultor y arquitecto. Alianza forma. 1983.

75. En la escuela vallisoletana, San José es relegado a un modesto segundo plano, y asiste a la escena como uno más de los personajes menores que intervienen. La Virgen centra la atención del artista al convertirse en la cosalvadora del mundo, junto a su Hijo.

76. En la pintura de Juan de Roelas era frecuente que a María se la representara como Madre de Dios, con su hijo en brazos, mostrándolo al mundo. Sin embargo, en el lienzo de la Adoración de los Pastores del convento de la Merced, la Virgen aparece arrodillada junto al pesebre, destapando el pañal para enseñar al Niño. Esta actitud maternal de María la había utilizado anteriormente Martínez Montañés en el retablo de San Isidoro del Campo en Santiponce, y posteriormente en el retablo del convento de Santa Clara de Sevilla. 
superior del lienzo de la Merced y del relieve de Olivares, aparezcan referencias claras a Dios Padre; en el primero a través de una imagen tangible, que vuela sobre un trono de ángeles, y en el segundo caso insinuando la presencia de Dios por medio de unas nubes que dejan pasar los rayos de luz.

Según Valdivieso ${ }^{77}$, uno de los aciertos de Juan de Roelas fue el saber humanizar las composiciones divinas para que, resultaran asequibles a las mèntalidades populares, así sus personajes mostraron expresiones ingenuas y sencillas que transmiten una suavidad espiritual. En sus obras las figuras adoptan posturas y expresiones anecdóticas, incluso caricaturescas, que humanizan aún más los temas. Quizá con la misma intención nos encontramos, en el relieve de Olivares, a un buey y una mula que asisten "sobrecogidos" a la escena del pesebre, elevando sus cabezas hacia el cielo cuando perciben la Luz divina.

Las formas del Sur llegan a Compostela en un momento en que en la ciudad trabajan pequeños talleres que mantienen todavía en sus obras, el reflejo de las recetas típicas de la generación anterior. Estos artesanos, anquilosados, permanecen al margen del lenguaje barroco de la escuela vallisoletana de Gregorio Fernández, y por supuesto desconocen las propuestas de los talleres de regiones más alejadas. En este ambiente pobre de recursos, Bernardo Cabrera debe de buscar un maestro capaz de esculpir el respaldo de la silla abacial de Olivares. Hoy desconocemos el nombre del artífice, pero en el relieve han quedado recogidos algunos de los rasgos que permiten relacionar con obras de la escuela orensana, concretamente del círculo del escultor Alonso Martínez ${ }^{78}$.

Bernardo Cabrera pasó aproximadamente seis meses fuera de Compostela, viajando y trabajando por las tierras del Sur, el encargo de la sillería de Olivares retrasó el ritmo de su taller, pero le brindó la oportunidad de conocer el ambiente artístico de la Sevilla de mediados del XVII, en un momento en que la ciudad vivió su etapa álgida como centro de las Artes y de la Cultura.

En la primavera de 1638 Cabrera estaba de vuelta en Santiago al frente de su taller. A partir de su regreso y hasta finales de la década del cincuenta, el maestro vivió una etapa muy dinámica y trabajó para las instituciones más relevantes de la región ${ }^{79}$. Durante los últimos años de su carrera intervino en algunas obras de arquitectura, pero lo realmente significativo fue que Bernardo Cabrera, junto a Mateo de Prado, formó el taller de retablos más importante de los años centrales del siglo XVII en Galicia.

77. VALDIVIESO, E.: Juan de Roelas. Sevilla 1979. p. 29.

78. VILA JATO, M.D.: Op. cit. p. 65

79. FERNÁNDEZ GASALLA, L: "La autoría del retablo de Montederramo: Bernardo Cabrera y su hijo Juan de Cabrera, retablistas del escultor Mateo de Prado". Brigantium, VI. (1989-1990).p. 175 y ss.; Aportación documental sobre a actividade artistica compostelana entre 1649 y 1686 . Tésis de licenciatura inédita. Santiago 1991.p. 71-74. 


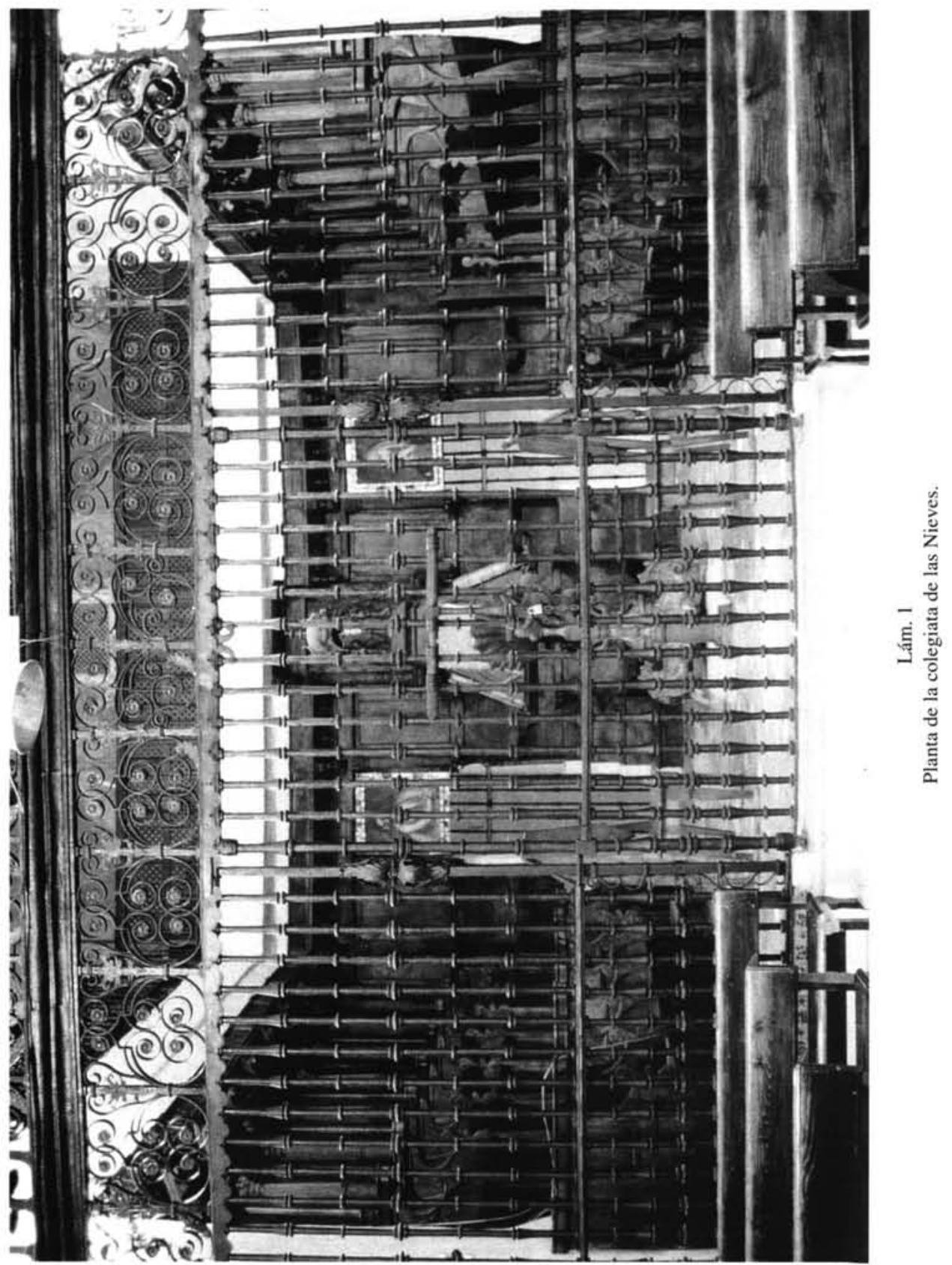




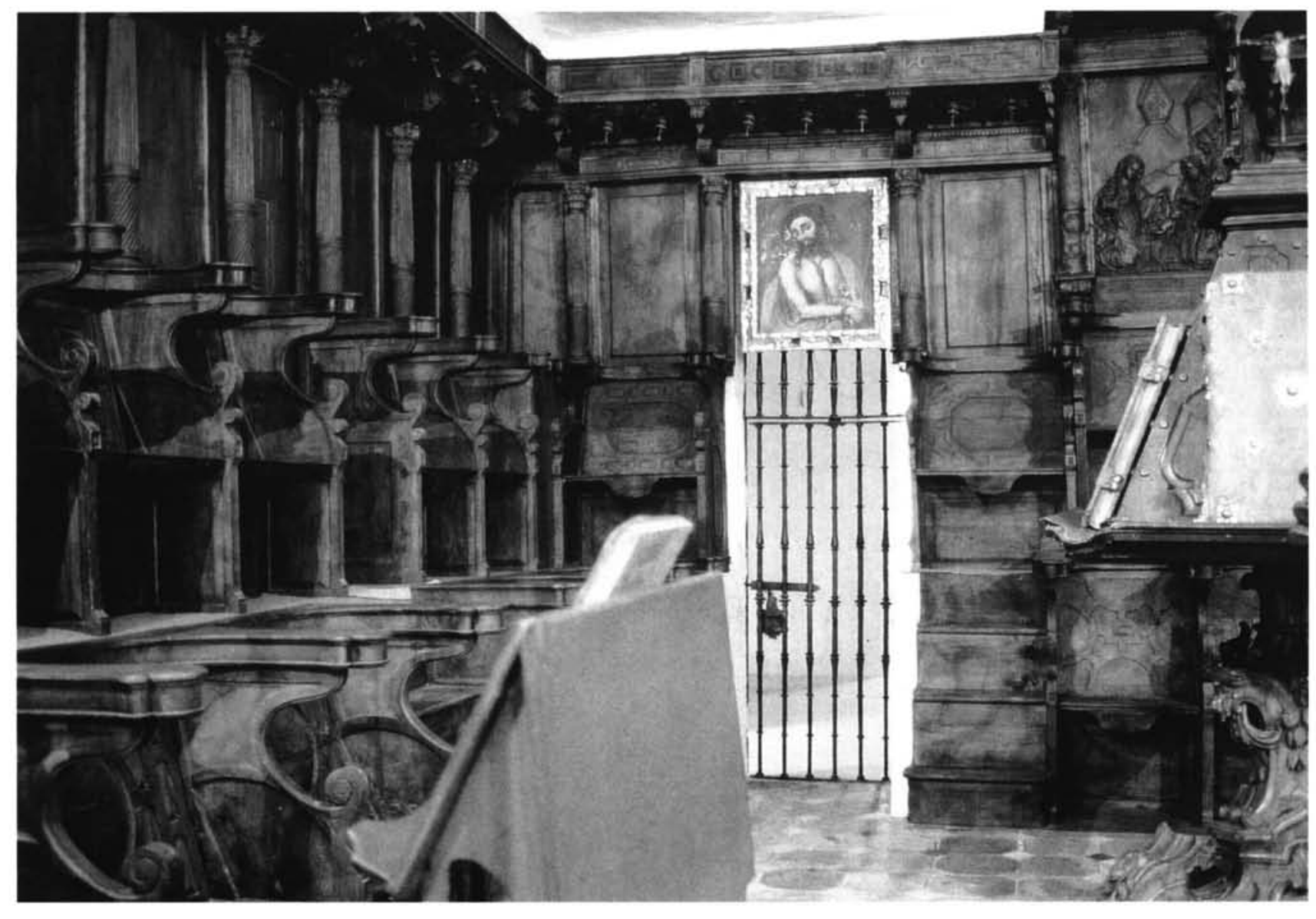


Obras en la colegiata de Olivares en la época del Conde-Duque: La sillería...

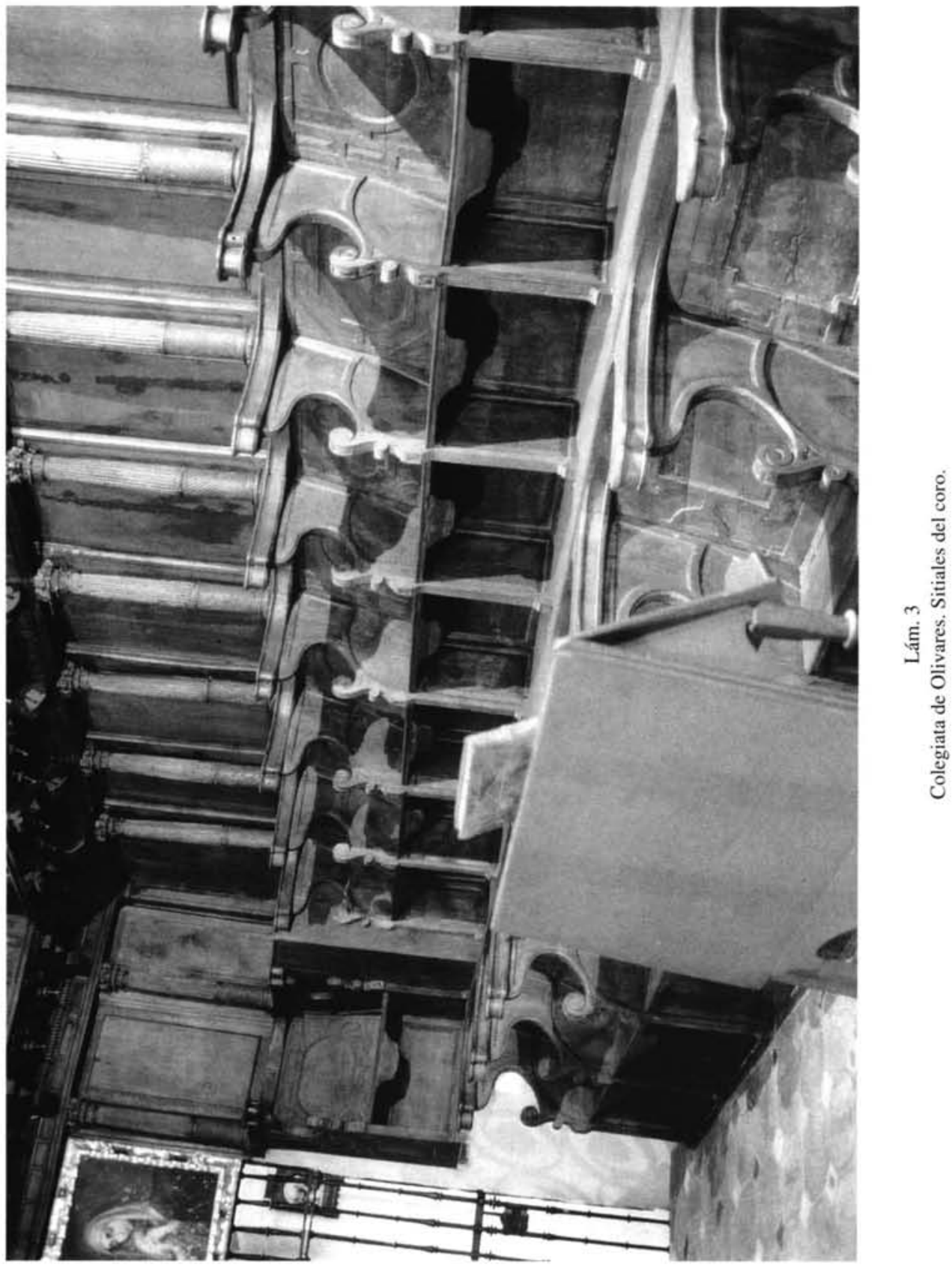




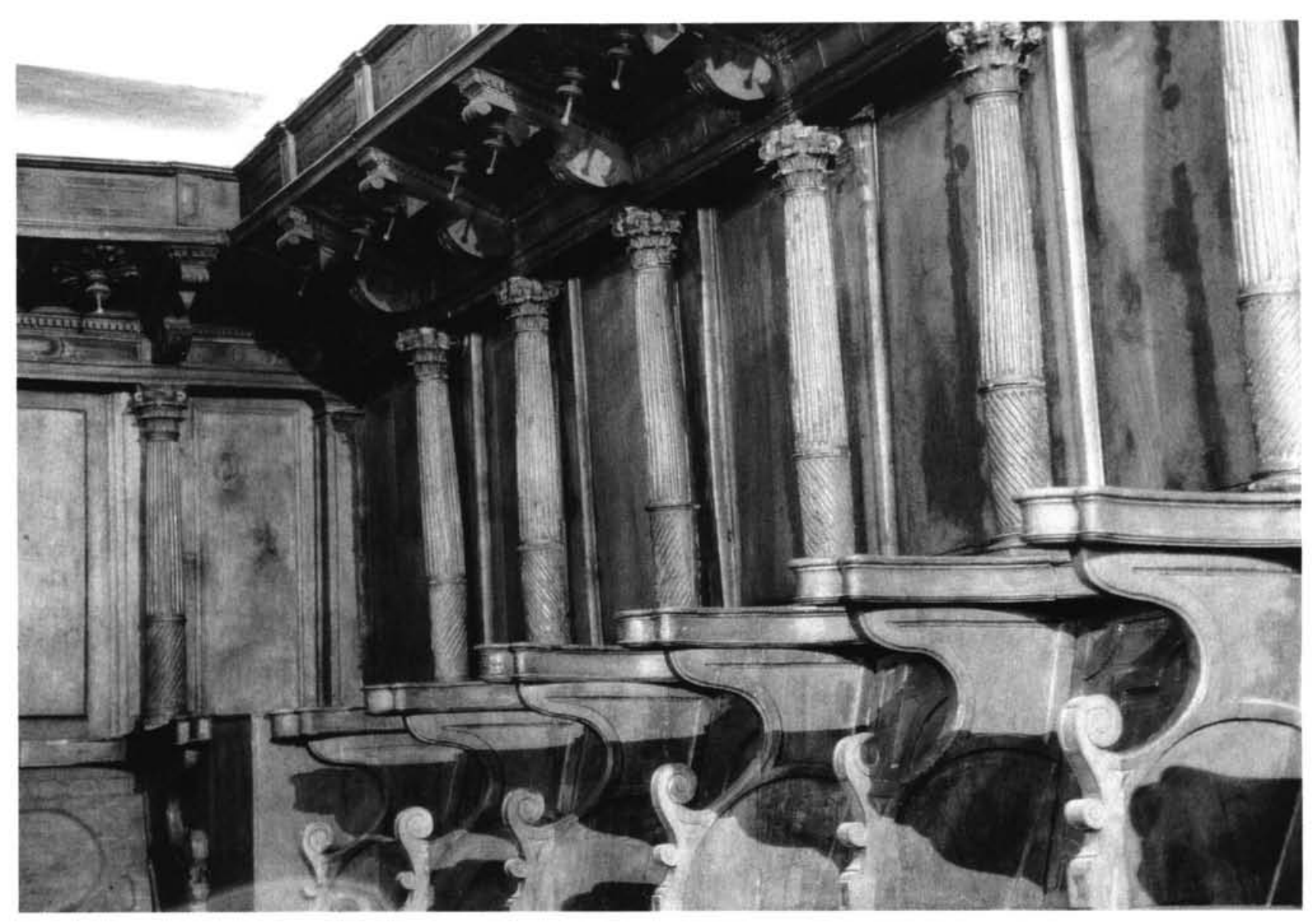

Lám. 4

Colegiata de Olivares. Sitiales del coro. 
Obras en la colegiata de Olivares en la época del Conde-Duque: La sillería...

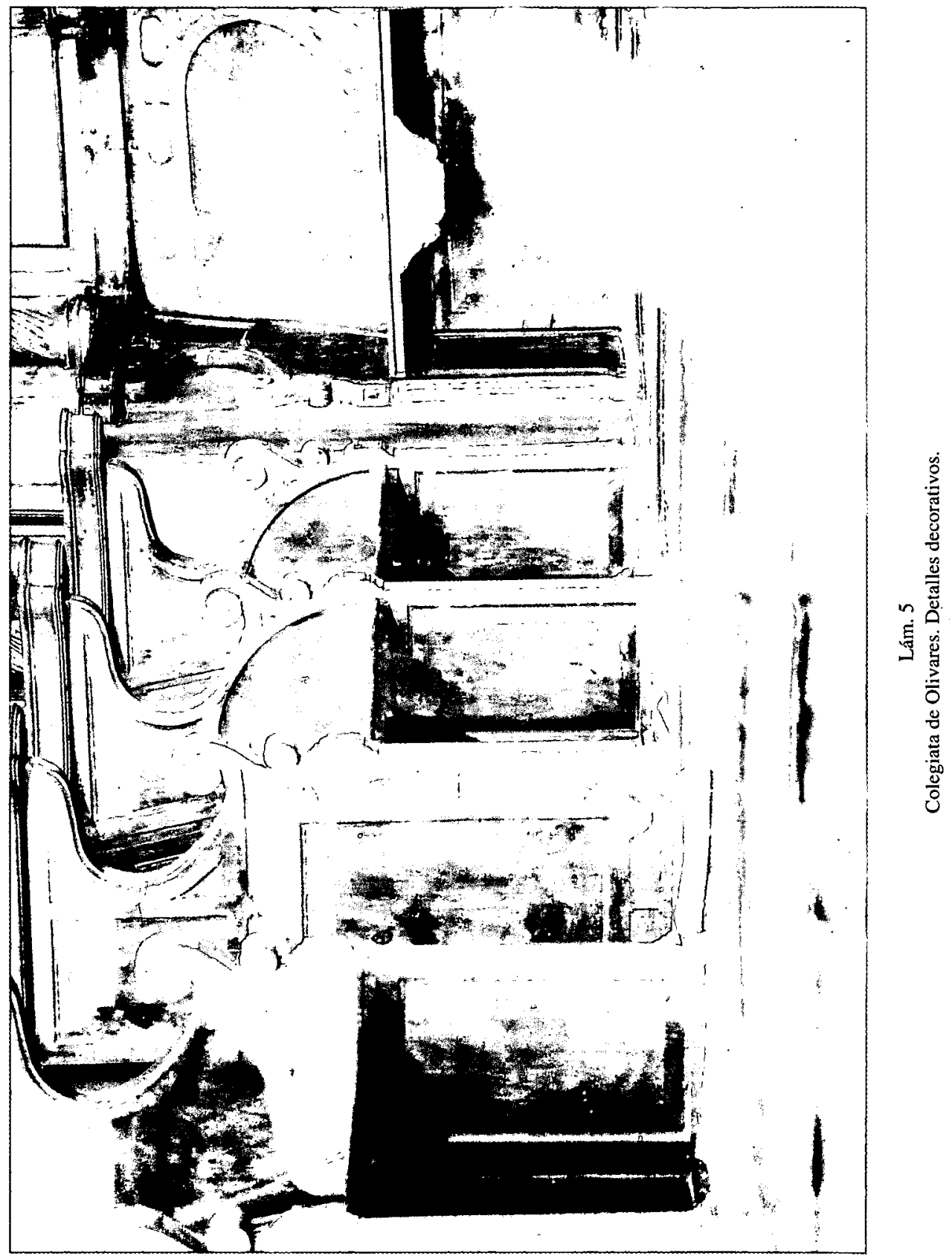


Obras en la colegiata de Olivares en la época del Conde-Duque: La sillería...

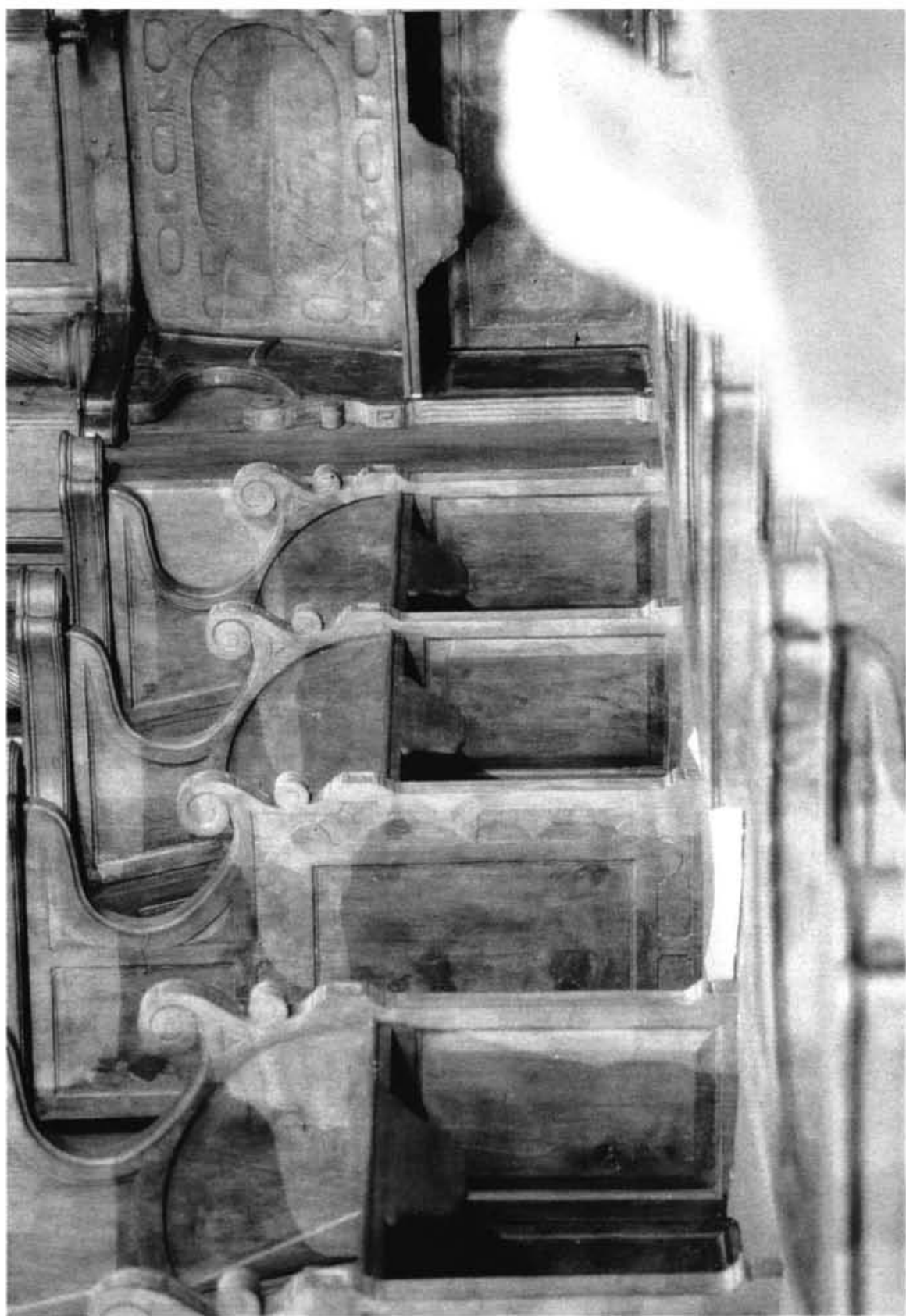

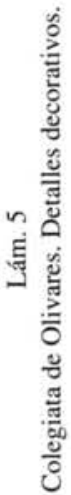




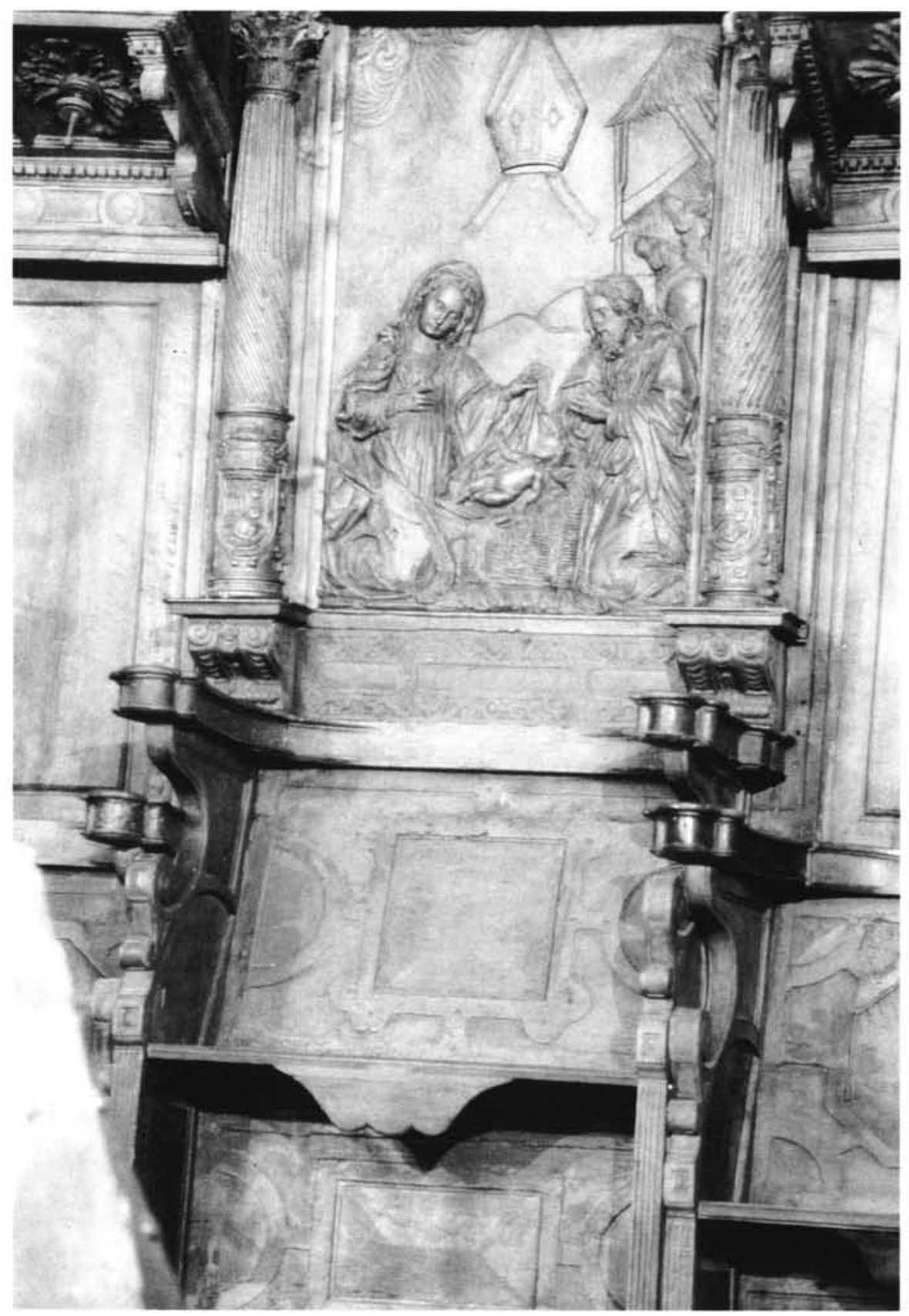

Lám. 6

Colegiata de Olivares. Silla abacial. 


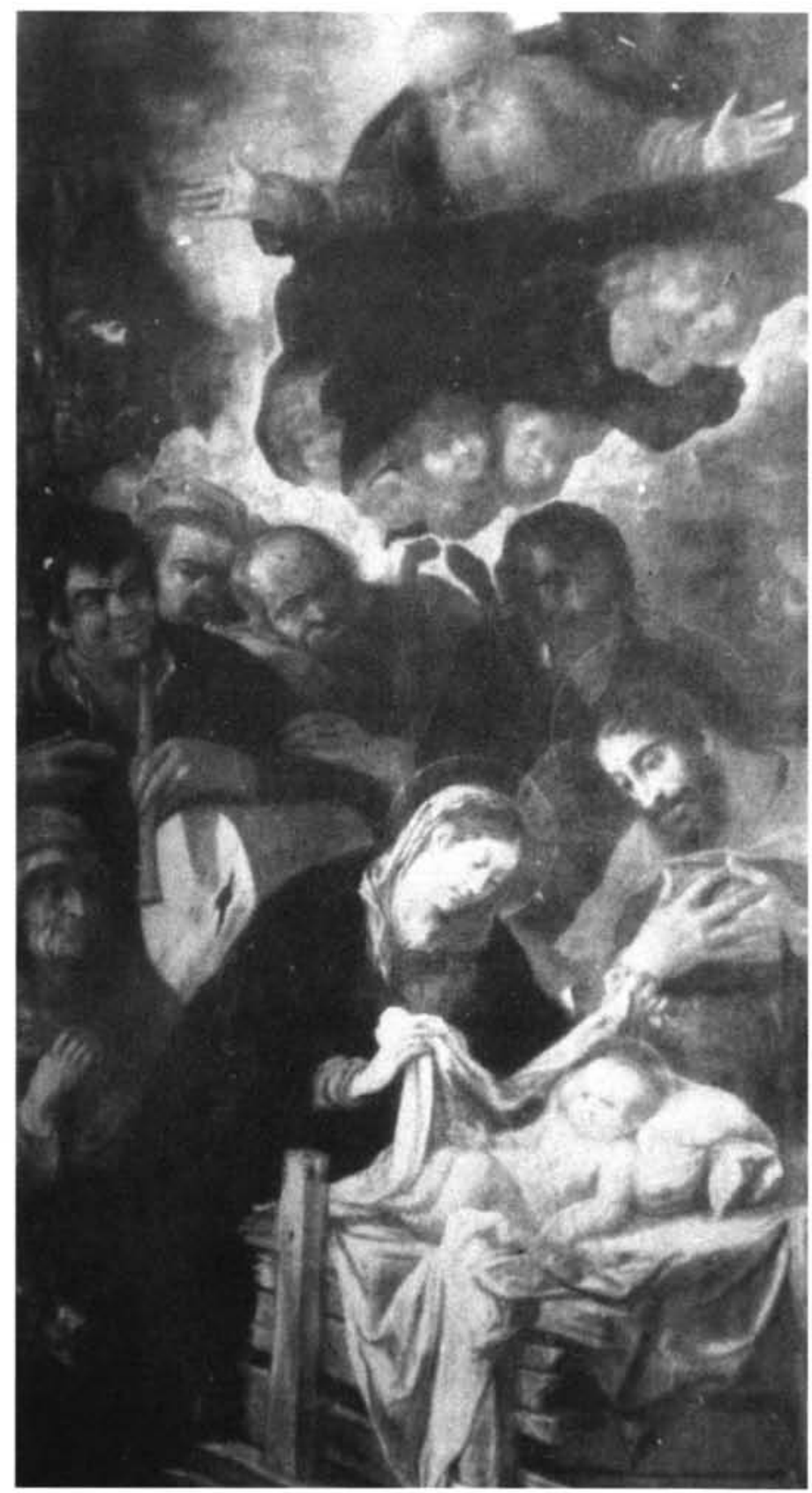

Lám. 7

Juan de Roelas. Adoración de los pastores. Retablo de la Merced de Sanlucar de Barrameda. 